\title{
VILNIAUS SENAMIESTIS - GYVOSIOS KULTŪRINĖS ATMINTIES ŠERDIS
}

\author{
Vytautas Rubavičius \\ Lietuvos kultūros tyrimu institutas, Saltoniškiu g. 58, 08105 Vilnius, Lietuva \\ El.paštas rubavytas@gmail.com
}

Iteikta 2011-10-21

\begin{abstract}
Santrauka. Vakarų pasaulyje miestai ir jų ryšių tinklai yra pagrindinė civilizacinės plètros ir kultūrinès kūrybos galia. Istorinis urbanistinis paveldas yra ne tik civilizacijos gèrybių sankaupa: jis palaiko ir tvirtina civilizacijos plètrai būtinus miesto bendruomenių tapatumus. Miestai yra regimas vietinių socialinių santykių, tarptautinių ryšių ir kuriamos kultūros erdvinès raiškos pavidalas. Miesto bendruomenių tapatumus formuoja ne tik miestiškų gyvenimo būdų visuma, bet ir regimi miestiški vaizdai, taip pat su jais siejami istoriniai kultūriniai bei sakraliniai simboliai ir prasmès. Istorinei kultūrinei atminčiai palaikyti bei tvirtinti svarbus yra tas urbanistinis paveldas, kuriame glūdi miesto tapatumo ir išskirtinumo bruožai, ịsitvirtinantys kultūrinèje atmintyje. Tokio paveldo branduolys ir šerdis, kurioje tarsi ịrašyta „genetinë“ konkretaus miesto raidos programa, - yra Senamiestis. Vilniaus Senamiestis savaip įkūnija ir Lietuvos valstybingumo bruožus. „Genetiniai“ miesto tapatumo ir išskirtinumo bruožai yra ir šiuolaikinės urbanistinès paveldo ekonomikos, taip pat kultūros industrijų „,ǐ̌tekliai“. Todèl urbanistinės veiklos Senamiestyje kriterijai turètų būti jo urbanistinès erdvinès struktūros, tapatumo ir išskirtinumo bruožų tvirtinimas, kultūrinės atminties gaivinimas ir sklaida, stiprinant miesto bendruomenès istorinių šaknų pajautą - įsigyvenimą ị miestą, taip pat paveldo ir kultūros industrijų išteklių gausinimas. Klausimas, kodèl iki šiol Lietuvoje dar nèra deramai suvokta Senamiesčio svarba valstybingumui ir nacionaliniam tapatumui tvirtinti, istorinès kultūrinès atminties gyvybingumui stiprinti, kūrybingai miesto bendruomenei ugdyti?
\end{abstract}

Reikšminiai žodžiai: kultūrinė atmintis, miestas, miesto bendruomenė, Senamiestis, tapatumas, urbanistinė veikla.

\section{Vieta ir žmogus}

Mūsų gyvenamojo meto esmè - judejimas, greitis. Kuo greičiau judame, kuo dažniau keliaujame - tuo šiuolaikiškesni. Vis sparčiau juda finansai, žmonès, prekès, paslaugos, studijų programos. Judriausias - kapitalas, nepaliaujamai ieškantis, kur pelningiausiai ịsivietinti. Paskui kapitalą juda šimtai milijonų žmonių, ieškančių darbo ir geresnio gyvenimo. Kapitalo laisvè - esminè šiuolaikinio pasaulio judrumo priežastis. Tad šimtai milijonų išvietintų ir pervietintų žmonių stengiasi suleisti šaknis naujose vietose arba mokosi gyventi bevietėse aplinkose. İsišaknydami naujose vietose žmonès stengiasi išlaikyti ryšius su gimtine. Tie ryšiai silpnejja, nes jų vaikams gimtinè jau yra naujoji vieta. Plinta diasporos, kurios tarsi puoselëja gimtinès vaizdinius ir palaiko buvusių vietų gyvybingumą. Kaip kalbèti apie egzistencini žmogaus ir vietos sąryšị, sandermę, regint greičio ir judejjimo ideologijos ịsigalèjimą? Juk daugelio žmonių tikslas yra gyventi ten, kur geriau jam ir jo vaikams. Gal pati tèviškès, gimtosios vietos, gimtojo miesto jausena jau yra jei ne atgyvena, tai tik graži poetinè mitologema, ne tiek padedanti, kiek trukdanti pasinaudoti naujomis, globalizacijos teikiamomis galimybemis.

Tačiau esama ir kito reiškinio. Pastaruoju metu žmonès negali né žingsnio žengti nefotografuodami ar nefilmuodami. Gal tai tik naujų technologijų nulemtas pomėgis, skatinantis vaizdų gamybą ir prekybą? Manytume, ne tik. Šitaip stengiamasi sukurti tam tikrus ryšius su tomis vietomis ir aplinkomis, kuriose buvojama. Drịstu teigti: kuo labiau ịsibejgeja žmogaus išvietinimo ir pervietinimo, jo atsaistymo nuo gimtųjų vietų vyksmas, juo labiau menksta gimtosios vietos pajauta, tuo labiau ryškeja poreikis savo atmintị pildyti ịvairių vietų vaizdais. Kitaip tariant, naujai ịsivietinama atmintyje, o tiksliau - skaitmeninèse technologijose. 
Žmogus visada vienaip ar kitaip susijęs su konkrečiomis vietomis. Jis gimsta tam tikroje vietoje, tam tikroje aplinkoje ir Anapilin išeina konkrečioje - palaidojimo vietoje. Tad vietos ir žmogaus ryšys - egzistencinis, būtiškas. Būti visada reiškia ir kur būti. Gimtinès vaizdas vienokiu ar kitokiu pavidalu išlieka žmoguje visą gyvenimą. Galime sakyti, jog vieta kildina žmogų, jo socialinę aplinką. Būtiškoji žmogaus ir vietos sandermè aiškiai išreikšta ir mituose, ir kalboje, kuri kreipia ị ịprastu žvilgsniu neregimus ir sunkiai apmąstymams pasiduodančius vietos ir žmogaus sąlyčio paribius, kur „žmogus yra savo vietoje“, o vieta yra žmogaus gyvenama. Visų tautų mitai vienaip ar kitaip nupasakoja jų gyvenamas aplinkas - kalnus, lygumas, dykumas ar jūras. Dievai ar kosminès jègos veikia atpažistamoje aplinkoje, kurios ypatumų negali suvokti bei išgyventi prašalaitis. Vietinèmis dievybèmis buvo pripažistami kalnai, uolos, upès ežerai. Kadangi mitai, kilmès pasakojimai palaiko socialinius tapatumus, tai tapatumams būdingas ir vietoviškumas. Iš socialinio "mes" - tapatumo kyla ir asmeninis tapatumas, kuris formuojasi ugdant savimonę. Kad ir kokia individuali savimonè taptų, ji negali visiškai „užmiršti “ gimtosios vietovès, gimtosios aplinkos. Galima tik sąmoningai ar nesąmoningai - atsiduodant įvairioms „bevietiškumo“ ideologijoms - tą vietoviškumą trinti. Mitai, istoriniai pasakojimai, literatūra, o sykiu šeima, kalba ir vietovè, jos į atmintị susigèrę vaizdai - tokie yra esminiai mūsų tapatumą formuojantys sandai. Tautinių, socialinių ir kitokių tapatumu „vietoviškumo“ bruožai atsiskleidžia lyginant ịvairių tautų mitus ir padavimus.

Vietos, vietovès egzistencinę svarbą individo tapatumui liudija ir kalba. Juk sakome, kad gyvenime būtina „rasti savo vietą“. Kalba nurodo, kad pati gyvenimo tèkmè yra būtina įvietinti, kad tik ịvietinta ji tampa žmogaus savasties pagrindu. Gyvenimas ne tik fiziškai gyvenamas tam tikrose vietose, bet ir kreipia žmogų i jo vietą, kuri apima esminius tapatumo bruožus - polinkius, profesiją, socialinius saitus. Palyginkime: „jis vis dar ieško savo vietos“ ir „jis jau rado savo vietą“. Iš šiu pasakymų ryškejja ir požiūris ị apkalbamus žmones, jų socialinis „svoris“. Tokia vietos svarba būdinga visam baltų ir slavų kalbų arealui. Juk ir mūsų miesto pavadinimas kilęs iš slavų miasto, tad miestai yra ypatingos žmonių santalkos vietos, kildinančios civilizacijas.

Žmogaus gyvenama vieta yra vietovè - konkreti giminystès, socialinių kultūrinių ryšių susaistytų ir kaimynystès aprépiamų vietų visuma. Ji savo vaizdiniais, kalbos lytimis yra tapatumo tvirtinimo medžiaga. Vietovè iš esmès nurodo ir žmogaus kilmę, kurios svarbą esame linkę primiršti. Juk klausiame - iš kur tas ar anas kilęs. Žmogaus kilmè, jo kilmingumas taip pat yra vietoviškas. Tad galima tvirtinti, kad esama egzistencinio vietos, vietoves, atminties ir tapatumo sąryšio ar sandermès. Suprantama, ta sandermé, nelygu istorinės aplinkybės, gali virsti ir nederme.

\section{Miestas ir Senamiestis}

Miestas yra ypatinga vieta ir vietové, sutelkianti daugybę žmonių ir paverčianti juos miestelènais. Miestai yra ypatingi dariniai kurti kultūrą ir civilizaciją, jie yra istorinių tautų gimdytojai. Miestas kildina ir telkia istorinę bendruomenę, o miestų ryšiai palaiko valstybę ir valstybingumą. Socialinès ir kultūrinès institucijos, pati šiuolaikinè institucinè valstybės sandara yra miesto produktas. Tačiau miestas yra ypatinga vieta ir kitu atžvilgiu. Savo tolesnius svarstymus paremsiu M. Heidegerio mintimis apie graikų šventovès pastatą - jis „stovédamas atveria pasauli ir kartu jị vèl grąžina žemèn, kuri tik dèl to tampa gimtąja“, ir pasitelksiu pasaulio nusakymą: „Pasaulis yra tolydžio atsiverianti plačių kelių atviruma, ir tie keliai - tai paprasti ir esminiai apsisprendimai tautos istoriniame likime" (Heidegeris 1980: 227, 231). Tad ì miestą dera žvelgti kaip í ypatingą vietą ir sykiu kūrini, kuris atveria žmonèms jų pasauli, savaip priartina tolumas, formuoja savitą, tik tam pasauliui būdingą tolimo ir artimo sąveikos konfigūraciją. Vienokia tolimo ir artimo sąveikos konfigūracija užkoduota Vilniuje, kitokia, pavyzdžiui, Klaipėdoje. Vieniems arti Varšuva, Krokuva, Polockas, kitiems - Karaliaučius, Ryga, Bremenas, Skandinavijos uostai. Valstybė vienaip ar kitaip tas konfigūracijas tarsi subendrina, bet jos išlieka miesto bendruomenių kultūrinëje atmintyje, nes palaikomos tiems miestams būdingų gyvenimo būdų dermès. Suprantama, jei gyvuoja istorinès miesto bendruomenès, kurių gyvybingoji atmintis siektų bent tris keturias kartas, kitaip tariant, bent šimtmetị.

Lietuvos miestai, kaip ir daugelis Vakarų civilizacijos urbanistinių darinių, rutuliojosi iš labai konkretaus vietos branduolio (žr. Šešelgis 1996), kuriame tarsi i̇rašyta genetinè raidos programa, nusakanti pirminị erdvinès struktūros ir atsivèrimo pasauliui pobūdị. Miestai ir kurti ten, kur labiausiai ryškèja „atsiverianti plačių kelių atviruma“, paženklinta miesto vartų ar uosto. Kad ir kaip istorija keistų miestų veidus, nèra sunku išskaityti jiems būdingą genetinę programą, kuri ir "laikoma“ ypatingoje saugykloje - Senamiestyje. Senamiestis yra gimties vieta ir raidos programa, kuri igyvendinama urbanistineje miesto bendruomenès veikloje. Senamiestis nulemia esminius miesto tapatumo ir išskirtinumo bruožus, kurie gali būti stiprinami ar silpninami įvairių miesto plètros sumanymų (plačiau apie miesto tapatumo ir išskirtinumo bruožus, 
taip pat Senamiesčio svarbą žr. Rubavičius 2005). Šiuo atžvilgiu svarbu suvokti, jog visokia miesto plètra, visokia naujų kvartalų statyba yra vienaip ar kitaip susijusi su Senamiesčiu miesto tapatumo ir išskirtinumo bruožų tvirtinimo požiūriu. Senamiestyje įrašytą genetinę raidos programą istoriškai papildo Senamiesčio ir Naujamiesčio ašis ir toje ašyje susiklostanti urbanistinè erdvinè struktūra.

\section{Miestas, kultūrinẻ atmintis ir miesto bendruomenè}

Miestas jame gyvenantiems žmonèms atveria pasauli. Šitai ir nusako Popiežiaus kreipimasis urbi et orbi - iš Romos atsiveria krikščioniškasis pasaulis, kurio keliai ir sueina į šį miestą, Romoje - krikščioniškojo pasaulio raidos programa. Miesto ir pasaulio sandermè kuria ir tvirtina esminius miestelènų tapatumo bruožus. Istorija liudija, kaip skyrèsi Senovès Graikijos miestų valstybių kultūra ir civilizaciniai užmojai, iš kurių ryškejo ir mentaliniai skirtingumai. Šitai pasakytina ir apie daugelį didžiųjų šiuolaikinès Europos miestų. Miesto atveriamas ir palaikomas pasaulis, jo „kelių atviruma" yra miestelènų pasaulis, grindžiantis jų gyvenimo būdą. İ tą pasaulį sunku ịsigyventi prašalaičiui, nes jam neprieinamas tas esminis vietos, miesto ir miestelènų sambūvị laiduojantis veiksnys - gyvoji kultūrine atmintis. Kultūrinè atmintis tvirtina ir palaiko visokius tapatumus - asmeninị, miestišką, tautinị, nacionalinị. Visuose esama jos kildinamų ženklų, vaizdų ir pasakojimų. Bendruomenès yra palaikomos ir skiriasi viena nuo kitos kultūrinès atminties turiniu bei „struktūra“ - ritualizuotais sugyvenimo būdais. Nesiimdamas detaliau gvildenti kultūrinès atminties sampratų ir tos atminties turinio (plačiau apie tai žr. Rubavičius 2011: 81-87), pažymèsiu tik keletą dalykų. Ši sąvoka išplito per Jano Assmanno (2006) veikalus jis plètoja kultūrinès atminties ar „veiklios atminties“ supratimą, kuris iškelia kultūrinių formų bei turinių reikšmę prisimenant bei ịsimenant ir veiklujji atminties pobūdị. Ta atmintis konstruojama ir rekonstruojama viešais prisiminimo veiksmais, ritualais, galimais nusakyti kaip minèjimai. Kultūriné atmintis apima tokị visoms visuomenèms visais laikais būdingą tinkamų naudoti tekstų, vaizdinių ir ritualų visetą, kurio „kultivavimas" padeda stabilizuoti ir perteikti visuomenès savivaizdị. Tad kultūrinè atmintis yra ir kolektyvinè, bendruomeniškumą laiduojanti atmintis, nes socialiniams saitams būdinga kultūros formos, o kultūros formoms - socialinis turinys bei komunikacinis pobūdis. Stengiantis paryškinti veiklųji prisiminimo pobūdị vartojama komunikacinès atminties sąvoka bendri prisiminimai ittvirtinami pasakojant, bendrau- jant, rodant, vaizduojant. Komunikacinè atmintis apima kasdienio bendravimo, žinijos, socialinių ryšių ir vaizdinių sritị, kuriai nebūdingas aiškus struktūruotumas. Kaip tik šioje atmintyje įrašytas socialumas ir bendruomeniškumas: „visuomenè įrašo save toje atmintyje su visomis savo normomis bei vertybèmis ir individe sukuria valdžią (authority), kurią Freudas pavadino superego ir kuri iš tradicijos vadinama "sąžine“ (Assmann 2006: 7). Komunikacinè atmintis laikoma kasdieniškuoju kolektyvinès atminties pavidalu. Vienas jos bruožų - ribotas gyvavimas praeities atžvilgiu: ji apima tris ar keturias kartas, kitaip tariant, beveik amžių. Tad galètume sakyti, jog toks ir turètų būti bent jau jauniausios veiksmingos miesto bendruomenès amžius. Suprantama, bent tiek ir turètų siekti tos bendruomenès lankomi ir prižiūrimi giminių kapai. Nors Assmannas kultūrinès ir komunikacinès atminčių skyrimą laiko svarbiu dalyku, manyčiau tą skyrimą esant gana sąlygišką - pavyzdžiui, tūkstantmečius „sutraukiantys" krikščioniškų, kalendorinių švenčių ar istorinių îvykių minèjimai struktūruoja ir kasdienès atminties, žinijos bei vaizdinijos veikimą. Tad kultūrinè atmintis veikia kasdieneje komunikacinejje atmintyje (mes labiau linktume sakyti bendravimo atmintyje) kaip bendri šią atmintị palaikantys, prasminius bei vertybinius orientyrus teikiantys, taip pat socialiniu ryšių bei ịvairių tapatumų tvirtumą laiduojantys „rèmai“. Kultūrine atmintis teikia socialinèms grupems prasmes jų sanglaudai ir išskirtinumui tvirtinti, taip pat tapatinimosi ir skirties jausenai ugdyti reikalingą žiniją ir vaizdiniją. Kaip tik ị vaizdą ir derètų atkreipti dèmesĭ, nes vaizdai ypač veikia atmintį. Individo tapatumo požiūriu svarbūs yra gimtinès, istorinių vietų bei paminklų, veikèjų, taip pat matytų filmų, paveikslų, ìsimintų ịvykių, artimų žmonių vaizdai ir atvaizdai. Daliai tų vaizdų būdingi etnokultūrinị, tautinị bei nacionalinị tapatumą formuojantys bruožai (plačiau žr. Stupples 2003). Tad suprantama, jog miestiečių tapatumui nepaprastai svarbūs yra atmintyje nusèdę gimtojo miesto vaizdai, miesto erdvių sąveikų vaizdynas.

\section{Vilniaus Senamiestis}

Jis yra ne tik Vilniaus, bet ir Lietuvos steigties vieta, iš kurios mums atsiveria ir valstybių pasaulis, valstybių sąryšių tolumos ir artumos. Lietuvių tauta per amžius išlaikè šios vietos svarbos pajautą - „mes be Vilniaus nenurimsim“. Tie žodžiai nèra banalūs, juolab nevertètų jų ironizuoti - juose glūdi supratimas, kad Vilnius yra ne tik kertinis valstybingumo akmuo, bet ir kartu su kalba esminè nacionalinị tapatumą formuojanti galia. Tačiau viena yra "nenurimti be Vilniaus“, o jau kas kita - ịsigyventi ị Vilnių, jo per šimtmečius 
artintą pasaulị ir būti vertiems Vilniaus. Vilniaus Senamiesčiui iškylančius iššǔkius bei jo išgyvenamas bėdas mes pabandysime apžvelgi keliais aspektais: kai kurių šiuolaikinio postmodernaus kapitalizmo sąlygų, miesto bendruomenès, kultūrinès atminties.

I aspektas. Staiga išsilaisvinusi iš sovietinès okupacijos ir perejjusi i postmodernaus kapitalizmo aplinką Lietuva pateko toje sistemoje veikiančių rinkos galių valdžion (plačiau apie postmodernaus kapitalizmo iškilimą bei jo kuriamas sąlygas ir raidos tendencijas žr. Rubavičius 2010). Kadangi finansinis kapitalas yra bankinis spekuliacinis kapitalas, tai vyrauja ekonomikos burbulų sektoriai, susiję su spekuliavimu vertybiniais popieriais, naujomis finansinemis „prekèmis“. Esminis postmodernaus kapitalizmo bruožas - išlaisvinto bankinio finansinio kapitalo veiklai būtinas ịsivietinimas ir persivietinimas. Tos veiklos padarinius matome sparčioje miestų raidoje, nes urbanistinè plètra, statybos ir perstatymai, susiklosčiusių urbanistinių erdvių „perdarymai“ tapo vienu svarbiausiu kapitalo apytakos veiksnių (apie globalizacinès urbanistinès plètros tendencijas ir jų antropologinius aspektus žr. Smart, Smart 2003). Tokiai finansinio kapitalo apytakai svarbi yra nekilnojamojo turto „gerintoju“", jo vertès didintojų, kurie Lietuvoje vadinami „vystytojais“, vadinamųjų developeriu veikla, kapitalą ir žemę paverčianti gyvenamojo ar kitokio ploto prekemmis. Nekilnojamojo turto rinkoje tai vienoje, tai kitoje šalyje išsipučiantys ir sprogstantys burbulai yra būdingi šiuolaikiniam kapitalizmui dèl finansinio kapitalo veiklos ir laisvų jo kelionių. Ekonomikos kilimas susijęs su vienokio ar kitokio pobūdžio burbulu pūtimu, o tie burbulai po kurio laiko neišvengiamai subliūkšta. Nelygu šalis, toks sprogęs burbulas gali paveikti ir regiono ar net pasaulio ekonomikos raidą. Lietuvos ypatumas tas, kad pastarojo meto nekilnojamojo turto burbulą padèjo pūsti ir valstybé, jos politikai, nepaisydami kai kurių ekonomistų perspejjimų apie neišvengiamą krizę. Politikų tikslas aiškus - didejjant pastatomų kvadratinių metrų kainai, daugiau surenkama ir pridètinès vertes mokesčio. Tokia politikų nuostata palengvina „vystytojų“ veiklą, nes jie tampa tarsi kapitalo laisvès atstovais, padedančiais greitai ir neskausmingai praturtèti dideliam su jų veikla susijusių verslininkų ir politikų sluoksniui. Vadinasi, kuo pigiau statyti ir kuo brangiau parduoti - tokia esminè ne tik „vystytojü“, bet ir juos aptarnaujančių architektų bei miesto planuotojų nuostata, kuri ir atliepia sisteminį kapitalizmo raidos ypatumą. Kadangi statoma ant žemès, tai visa ši veikla grindžiama sieku gauti kuo didesnị pelną iš žemès sklypo, ị kurị žvelgiama kaip ị tam pelnui gauti reikalingą „nuogą“ teritoriją. Tad spekuliacija žemès sklypais, kuri vyksta vietos politiku priežiūros lauke, yra svarbus finansinio kapitalo įsivietinimo ir persivietinimo veiksnys. Bandant suvokti šiuolaikinès urbanizacinès plètros ir su ja susijusios miestų politikų, planuotojų, architektų veiklos pobūdị ir paskatas, dera turèti omenyje iškilaus finansinio kapitalo metamorfozių, jo erdvinès ir kultūrinès raiškos analitiko Fredrico Jamesono aiškinimą, kad investicijoms pereinant nuo gamybos į spekuliacijas akcijų rinkoje, o finansams globalizuojantis, nepaprastai aršèja kova dèl nekilnojamo turto vertès (Jameson 2002: 198). Tą vertę ir siekiama dirbtinai padidinti, iš žemès sklypo gaunant kuo daugiau kvadratiniu metru parduotino ar išnuomotino ploto. Šiam imperatyvui pajungiama miesto planuotojų ir architektų veikla, kurioje visokie istorinio, saugotino ar puoselètino paveldo dalykai suvokiami vien kaip trukdžiai gauti didesnę investicijų "grąžą“. Toki veiklos pobūdį ir jo kildinamą mentalitetą ịtvirtina ir itteisina Lietuvoje įsivyravusi miestų raidos planavimo veikla ir įstatymai, kuriuose nebeliko - palyginti su sovietiniais metais - urbanistinio supratimo. Ši beda, neigiamai veikianti visą valstybès raidą, mūsų urbanistu yra iškelta ir aptarta (Juškevičius, Valeika 2007; Juškevičius, Gaučè 2010), tačiau kol kas nematyti jokių poslinkių, kad miestų planavimo dokumentuose būtų išreiškiamas šiuolaikinis urbanistinis požiūris ị miestų raidą ir jos planavimą.

Šiuo atžvilgiu dera prisiminti sovietinius metus. Tuomet miestų projektavimo ir urbanistikos statusas buvo labai aukštas. Tai lèmè ne tik sovietinè naujo gyvenimo, naujos aplinkos ir naujo žmogaus kūrimo ideologija, bet ir didžiulè industrinès plètros apimtis, susijusi su naujų teritorijų įsisavinimu ir žmonių masių (darbo jègos) perkèlinèjimu, jų gyvenimui reikalingos socialinès ir kultūrinès infrastruktūros kūrimu. Todèl miestų planuotojų mentalitete vyravo urbanistinis mąstymas: naujų miestų, jų kvartalų ir kitokių statinių projektavimas buvo grindžiamas ekonominès raidos, industriniais tikslais, socialinès ir kultūrinès infrastruktūros dalykais, kitaip tariant, užstatomai teritorijai buvo teikiamas būdingas ekonominis ir sociokultūrinis turinys. Jei dar pridetume istorinio urbanistinio paveldo dèmení, gautume šiuolaikiško vakarietiško miestų planuotojų ir urbanistų mentaliteto branduolį. Šiuo aspektu iškilus yra Kazio Šešelgio darbas. Drįstu teigti, kad jo idejos ir principai darosi vis aktualesni ne tik sveiko pasipriešinimo „kvadratinių metrų“ ideologijai ir mąstymui požiūriu, bet ir kaip šiuolaikiško vakarietiško urbanistinio mąstymo apraiška. Kas šiuo metu tarp miesto planuotojų mąsto socialinèmis ir kultūrinemmis kategorijomis ar visuomenei aiškina, jog statant bei rekonstruojant būtina „pasiekti tolygų visu šalies gyventoju buitinị ir kultūrinị aptarnavimą“ (Šešelgis 2000: 205)? Ar galètume pasakyti, jog šiuo 
metu jau nebesvarbūs yra jo nusakyti tokie Lietuvos teritorijos bendrosios apgyvendinimo schemos sukūrimo rezultatai, tarp kurių ypač ịsimintinas šis: „išryškinta urbanistinių (kraštovaizdžio organizacija) ir socialinių (gyventojų aptarnavimas, poilsio organizacija) veiksnių reikšmė rekonstruojant gyvenamųjų vietų tinklą" (Šešelgis 2000: 270)? Urbanistai labai aiškiai skyrè miestų teritorijas nuo kitokio pobūdžio teritorijų. Deja, urbanistinès teritorijos supratimo buvo atsisakyta išsilaisvinus iš sovietinès okupacijos. 1995 m. priimtas, vèliau tobulintas ir šiuo metu galiojantis $2006 \mathrm{~m}$. redakcijos teritorijų planavimo įstatymas paremtas tuščios vietos, tuščios teritorijos supratimu. Teritorijos atžvilgiu visos vietos yra lygiavertès. Tame įstatyme „nèra jokios užuominos, kad miestas ir stambios ar mažos jo dalys, miestų regionai ir kitos gyvenamosios vietovès - tai hierarchinès sistemos, tarpusavyje susijusios sisteminiais ryšiais“" (Juškevičius, Gaučè 2010: 196). Ką jau kalbèti apie tiems ryšiams būdingą ekonomini ir sociokultūrinị turinị. Vèlgi nulemia jau minèti vadinamųjų developerių ir su jais susijusių naujųjų miestų valdytojų interesai - kurti kuo laisvesnę sprendimams priimti aplinką.

II aspektas. Genetinei miesto raidos programai rutuliotis būtina istorinè kultūrinès atminties saistoma bendruomenè, gyvenanti savame, gimtajame mieste. Miestiško gyvenimo būdo bendruomenès susiklosto per kelias kartas. Tik per kartas įaugama ị miestą ir tampama miesto civilizacijos kūrèjais. Miestas su visa savo istorija ir kultūra turi būti gimtas ne vienai kartai, kad deramai būtų valdomas ir puoselejamas. Vilniui, kaip ir Klaipedai, nepasiseke - po karo jie neteko savo gyventojų, tad miestiečiais tapo atvykèliai. Kultūros žmonemis tapo kaimo vaikai, kurių vaikai ir anūkai jau ima kurti gimtąji Vilnių. Beje, diduma pirmosios pokario kartos žymiausių lietuvių architektų ir urbanistų - kaimo ir miestelių jaunimas (Mačiulis 2011: 19-20), tad miestas jiems - išmoktas. Blogiau ar geriau. Tačiau istorinis urbanistinis Vilniaus paveldas nebuvo ir kol kas dar nèra deramai išgyventas ir j̦sisąmonintas jau vien dèl jame nugulusių skirtingų kultūrų sluoksnių, kuriems gaivinti stokojama ir kultūrinès kūrybos patirties, ir kultūrinio akiračio. Kitas svarbus dalykas miesto valdymas daugiausia priklauso nuo atvykèlių, kaimuose ir miestelių „chruščiovkèse“ augusių žmonių, kurie čia atvyko susikurti sau gerą gyvenimą. Ir kuo greičiau. Jiems miestas - pirmiausia jų asmeninè gyvenamoji vieta, kuri formuojama pagal savo norus ir neskoningas fantazijas. Pastarųjų raiškos rezultatai matyti daugelyje Vilniaus senamiesčio vietų, ypač Užupyje. Vilniui vis labiau plečiantis, o jo ekonomikai priklausant nuo nekilnojamojo turto rinkos, i̇ miestą iš rajonų plūsta darbo jèga, kuri taip ir netaps vilniečiais.
Jiems miestas - tik laikina gyvenvietė. Suregistravęs Vilniaus Senamiestyje vykdytus griovimo darbus, rekonstrukcijas, kuriomis naikinamas išlikęs urbanistinis paveldas (beje, tokia praktika būdinga ir kitiems didmiesčiams, ypač nuo to kenčia Klaipeda), ir akivaizdžiai parodęs, kaip nesilaikoma ne tik prisiimtų tarptautinių ịsipareigojimų saugoti Senamiestị, bet ir savų ístatymų, Algimantas Gražulis rašo: „Susidaro ispūdis, kad nei Lietuvos politinis elitas, atstovaujantis Lietuvai ir tarptautiniu lygiu, nei atsakingi valstybès tarnautojai vis dar nesuvokia, kad Vilniaus istorinis centras - tai iškiliausia mūsų šalies kultūros paveldo dalis“(Gražulis 2010, 3: 16). Galime pridurti, kad nesuvokia ir to paveldo reikšmés nacionaliniam tapatumui bei valstybingumui tvirtinti ir skleisti.

Išsamiai besiformuojantị modernụji Vilniaus centrą urbanistiniu požiūriu išgvildenęs ir apgailestaujantis, kad per du nepriklausomybès dešimtmečius valstybingumas urbanistiškai taip ir nebuvo įprasmintas, Saulius Motieka susiklosčiusią padètị nusako taip: „parengti ir šiuo metu galiojantys detalieji planai yra sukurti tam, kad visą teritoriją būtų galima pasiskirstyti itakos zonomis. <...> Tokiuose teritorinio planavimo dokumentuose reglamentuojama ne urbanistine architektūrinè kokybè, o tik užtikrinama maksimali esamos nuosavybès galimos realizacijos apimtis, tenkinanti privačius interesus" (Motieka 2009: 196). Šitai iš dalies ir aiškintina aptartais mentaliteto bruožais, gyvybingos, miesto civilizacijos aplinkoje brendusios ir tą civilizaciją kūrusios miesto (urbanistinès) bendruomenès stoka. Ją nulėmè ne tik pokarinis Vilniaus ir Klaipedos „íšvalymas“, bet ir tam tikri Lietuvos visuomenès istorinès raidos ypatumai, $\mathfrak{i}$ kuriuos kreipia Šešelgio įžvalga, kad „Lietuvoje nesusikloste tvirtas ir vieningas miestiečių luomas“"(Šešelgis 1996: 53). Deja, ši tema kol kas nesusilaukè tyrèjų dèmesio.

III aspektas. Gyvybingą ir kūrybingą kultūrinę atminti palaiko bendruomené, kuriai ta atmintis laiduoja bendruomeninius saitus ir tapatumą. Jau minejjau, jog bendruomenès komunikacinè atmintis siekia šimtmetị, tad bent jau tokio jaunumo turètų būti ir miestiečių bendruomenè. Suprantama, ir atvykèliai gali daug ką prisiminti ir ị daug ką ịsigyventi, tačiau turètų turèti ir bendresnị jų tapatumą laiduojantị religinị kultūrinị pamatą. Sovietiniais metais tokie pamatai nebuvo kuriami, priešingai - buvo stengiamasi sunaikinti ar pakeisti simbolinį istorinio paveldo turinį, kreipiantị žmones ị tuos laikus, kurie gyvavo prieš sovietinio pasaulio sukūrimą, - menančius „aną Lietuvą“, „aną, iki 1917-ųjų pasaulį“. Istorinių, sakytume, šakninių, miesto bendruomenių reikšmè šiuo metu dideja, nes bendruomeninius ryšius, tradicines bendruomenes „naikina“ vadinamųjų developeriu veikla - gentrifi- 
kacija ir kraustymasis, susijęs su nekilnojamojo turto burbulais, - o jų atmintị veikia drastiškas urbanistinès aplinkos keitimas. Nepadeti ir realios savivaldos pamatai, kurie atvykèlius skatintų kuo greičiau įsivietinti, nes jų supratimas reikalingas tvarkant gyvenamąją aplinką. Todèl būtinos sąmoningos pastangos telkti miesto bendruomenę, kuriant ir ịtvirtinant jos kultūrinę atmintị. Šiuo atžvilgiu urbanistinè veikla yra bene svarbiausia. Kodèl? Urbanistinès veiklos apimtis yra labai didele, ji tvarko erdvinę žmogaus aplinką, naujai ją îvaizdina ir šitaip veikia atmintį bei pasaulèvoką. Jau pamažu imama suvokti išskirtine istorinio urbanistinio paveldo reikšmè vis labiau kultūriniu virstančio turizmo industrijai: jai ypač svarbus to paveldo vizualinis aspektas, kuris ir „vartojamas“. Tačiau vizualinis aspektas yra vienas svarbiausių veiksnių, formuojančių individualų ir grupinį tapatumą (Tilley 2006). Tie vaizdai nugula žmonių atmintyje ir sieja juos su gimta vieta, vietiniais „bendravaizdžiais“ ar ị̌saknija atvykèlius. Kuo didesnis tų vaizdų simbolinis bei sakralinis turinys, tuo jie veiksmingesni tapatumo tvirtinimo atžvilgiu. Urbanistine veikla gali remtis simbolių ir ženklų paveldu, o gali ji ir naikinti. Remdamasi tuo paveldu, urbanistinè veikla veiksmingiausiu - kasdienio poveikio - būdu simbolių ir ženklų turinị ịskiepija ì miestiečių sąmonę. Vieniems - tai iš pradžių nelabai suprantamas priminimas, o jau tų ženklų aplinkoje augantiems - natūralus gimtojo miesto bruožas, padedantis jiems įsišaknyti daugiakultūriniame šimtmečių pavelde ir paversti jị kūrybinę galią didinančia gyvenamąja terpe.

\section{Vietoj išvadų}

Lietuvos urbanistinejje veikloje būtini esminiai principinių nuostatų ir mentaliteto pokyčiai. Pirmiausia reikètų išsiaiškinti socialinius ir kultūrinius tos veiklos uždavinius bei jų igyvendinimui kylančius iššūkius. Nuostatos ir principai turètų kisti atsižvelgiant j̇ urbanistinę plètrą skatinančias postmodernaus kapitalizmo sąlygas ir iš jų kylančius iššūkius. Tad pirmiausia - sąmoningai priešintis „naudingo ploto“ ideologijai. Suprantama, nèra jẻgos, kuri iš esmès keistų dabartinio kapitalizmo būseną, tad naivu būtų kovoti su greito ir kuo didesnio pelno imperatyvu, tačiau svarbu yra ji suvokti ir derinti su kitokiais urbanistinès veiklos tikslais bei būtinais prioritetais. Juos svarstant kaip tik ir derètų atsižvelgti $\mathfrak{i}$ anksčiau aptartas stokas - miesto bendruomenès ir kultūrinès atminties. Tad centrinès miesto dalies, o ypač Senamiesčio renovacijos projektai ir turètų būti vertinami kultūrinès atminties gaivinimo ir gyvybinimo, miesto bendruomenès stiprinimo požiūriu. Esminis, sakytume, atskai- tos taškas - istorinès urbanistinės erdvinès aplinkos struktūros tvirtinimas, apimantis susiklosčiusị gatvių tinklą ir statinių tūrių bei jų vaizdų sąveiką. Tam būtini ir dideli atstatymo darbai, kuriuos derètų vadinti atkuriamąja renovacija. Tarptautinis Didžiosios žydų sinagogos atstatymo projektas būtų naudingas kaip einanti po Valdovų rūmų urbanistinès struktūros tvirtinimo, o sykiu paveldèto kultūrinio simbolinio turinio gaivinimo pakopa. Tačiau esama ir mažesniu daug nekainuojančiu ir tik nuo savivokos priklausančių darbų. Pavyzdžiui, centrinèje miesto dalyje buvusių kapaviečių pažyméjimas ir juose palaidotų žmonių pavardžių paviešinimas. Tos vietos su autentiškais buvusiais įrašais ir paminklų detalių kompozicijomis galètų tapti tokia pat ịprasta miestiečiams aplinka, kaip ir nauji barai bei gyvenamieji stiklainiai. Mūsų darbai ir apmąstymai turètų nurodyti „kelią, vedantị ì mūsų prieglobsčio vietą. Ši vieta visada yra istoriška, t. y. nulemta mūsų misijos, nepriklausomai nuo to, ar mes ją vaizduojamès, nagrinèjame ir tvarkome istoriškai, ar mes tikimès, savavališkai nusisukdami nuo istoristikos, dirbtinai išsivaduoti iš mūsų istorinio likimo" (Heidegeris 1992: 264). Likimo mums dovanoto vienintelio istorinio prieglobsčio ir pasaulio atverties vietos puoselejimas - tokia, trumpai tariant, turètų būtų urbanistinès renovacinès veiklos ideologija.

\section{Literatūra}

Assmann, J. 2006. Religion and Cultural Memory: Ten Studies. Transl. Rodney Livingstone. Stanford, CA: Stanford University Press.

Gražulis, A. 2010. Vilniaus senamiesčio žaizdos. Pastarųjų 15 metu pokyčiai ir tendencijos, Kultūros barai 3: 14-24; ir 4: $18-27$.

Heidegeris, M. 1992. Rinktiniai raštai. Iš vok. k. vertė A. Šliogeris. Vilnius: Mintis.

Heidegeris, M. 1980. Meno kūrinio prigimtis, iš B. Kuzmickas (sud.). Grožio kontūrai. Vilnius: Mintis, 208-255.

Jameson, F. 2002. Kultūuros posūkis. Rinktiniai darbai apie postmodernizma (1983-1998). Iš anglų k. vertė Auksè Mardosaitè. Vilnius: Lietuvos rašytojų sąjungos leidykla.

Juškevičius, P.; Gaučè, K. 2010. Urbanistinio planavimo deformacijos, Urbanistika ir architektüra [Town Planning and Architecture] 34(4): 195-207. doi:10.3846/tpa.2010.19

Juškevičius, P.; Valeika, V. 2007. Lietuvos miestu sistemu raida. Vilnius: Baltijos kopija.

Mačiulis, A. 2011. Vytautas Edmundas Čekanauskas. Vilnius: Vilniaus dailès akademijos leidykla.

Motieka, S. 2009. Besiformuojančio Vilniaus moderniojo centro urbanistinis modelis, Urbanistika ir architekt $\bar{u}$ $r a$ [Town Planning and Architecture] 33(4): 195-210. doi:10.3846/1392-1630.2009.33.195-210

Rubavičius, V. 2011. Kolektyvinè atmintis laisvinantis iš sovietinès okupacijos, Metai 10: 79-93.

Rubavičius, V. 2010. Postmodernusis kapitalizmas. Kaunas: Kitos knygos. 
Rubavičius, V. 2005. Miesto tapatumas ir išskirtinumas globalizacijos sąlygomis, Urbanistika ir architektūra [Town Planning and Architecture] 29(4): 158-163.

Smart, A.; Smart, J. 2003. Urbanization and the Global Perspective, Annual Review of Anthropology 32: 263-285. doi:10.1146/annurev.anthro.32.061002.093445

Stupples, P. 2003. Visual Culture, Synthetic Memory and the Construction of National Identity, Third Text 12(2): 127-139. doi:10.1080/09528820309661

Šešelgis, K. 2000. Gyvenimas. Mokslo darbai. Vilnius: Technika.

Šešelgis, K. 1996. Lietuvos urbanistikos istorijos bruožai: nuo seniausių laiku iki 1918 m. Vilnius: Mokslo ir enciklopedijų leidykla.

Tilley, Ch. 2006. Introduction: Identity, Place, Landscape and Heritage, Journal of Material Culture 11(1/2): 7-32. doi:10.1177/1359183506062990

\section{VILNIUS OLD TOWN - THE CORE OF THE LIVING CULTURAL MEMORY}

\section{Rubavičius}

Abstract. In the Western world, cities and urban networks are the basic cultural and civilizational force. Urban historical heritage grounds and strengthens identities of urban communities, which are essential for civilizational development. Cities are visual shapes of the processes of local social and international relations and cultural production. The identities of urban communities are formed not only by their urban lifestyles, but also by urban visual surroundings with cultural and religious symbols and meanings. Urban historical heritage is the source of urban uniqueness and identity, thus it plays an important role in cultural memory formation and maintenance. The old town is the core of this kind of heritage where "genetical" programme of urban development is inscribed. In addition, the Old Town of Vilnius embodies the main features of Lithuanian historical statehood. Thus, the criteria of urban developmental works in the Old Town area should rely on the tasks of the reinforcing both urban space structure and the features of urban identity and exceptionality, and also on the sustainment and spread of cultural historical memory ensuring identity of the urban community.

Keywords: city, cultural memory, identity, Old Town, urban community, urban development.

\section{VYTAUTAS RUBAVIČIUS}

Doctor of Philosophy, senior research worker. Lithuanian Culture Research Institute. Saltoniškiu g. 58, 08105 Vilnius, Lithuania. E-mail: rubavytas@gmail.com.

Research interests: postmodern discourse, postmodern urbanism, globalization, cultural memory and national identity. 